\title{
Repeated Quinpirole Treatment Increases cAMP-Dependent Protein Kinase Activity and CREB Phosphorylation in Nucleus Accumbens and Reverses Quinpirole-Induced Sensorimotor Gating Deficits in Rats
}

\author{
Kerry E Culm', Natasha Lugo-Escobar', Bruce T Hope ${ }^{3}$ and Ronald P Hammer Jr*, 1,2 \\ 'Departments of Pharmacology and Experimental Therapeutics, Tufts University School of Medicine, Boston, MA, USA; ${ }^{2}$ Neuroscience, Anatomy \\ and Psychiatry, Tufts University School of Medicine, Boston, MA, USA; ${ }^{3}$ Behavioral Neuroscience Branch, National Institute on Drug Abuse, \\ Intramural Research Program, Baltimore, MD, USA
}

\begin{abstract}
Sensorimotor gating, which is severely disrupted in schizophrenic patients, can be measured by assessing prepulse inhibition of the acoustic startle response (PPI). Acute administration of $\mathrm{D}_{2}$-like receptor agonists such as quinpirole reduces PPI, but tolerance occurs upon repeated administration. In the present study, PPI in rats was reduced by acute quinpirole (0.I mg/ $\mathrm{kg}$, s.c.), but not following repeated quinpirole treatment once daily for 28 days. Repeated quinpirole treatment did not alter the levels of basal-, forskolin- $(5 \mu M)$, or SKF 82958- $(10 \mu \mathrm{M})$ stimulated adenylate cyclase activity in the nucleus accumbens (NAc), but significantly increased cAMPdependent protein kinase (PKA) activity. Phosphorylation of CAMP response element-binding protein (CREB) was significantly greater in the NAc after repeated quinpirole treatment than after repeated saline treatment with or without acute quinpirole challenge. Activation of PKA by intra-accumbens infusion of the cAMP analog, Sp-cAMPS, prevented acute quinpirole-induced PPI disruption, similar to the behavioral effect observed following repeated quinpirole treatment. Thus, repeated quinpirole treatment increases NAc PKA activity and CREB phosphorylation, and this neuroadaptive response might facilitate the recovery of sensorimotor gating in schizophrenia.

Neuropsychopharmacology (2004) 29, I823-1830, advance online publication, 12 May 2004; doi: I 0. I038/sj.npp. I 300483
\end{abstract}

Keywords: prepulse inhibition; schizophrenia; $D_{2}$-like receptors; PKA; phospho-CREB; nucleus accumbens

\section{INTRODUCTION}

Deficits in sensorimotor gating that may lead to sensory flooding and cognitive fragmentation in patients with schizophrenia can be detected across species by quantifying prepulse inhibition of the acoustic startle response (PPI). Normally, forebrain processing of information contained within a prepulse stimulus can inhibit brain stem startle responses to a subsequent pulse stimulus. Several neurotransmitters and their respective receptors, including dopamine $\mathrm{D}_{2}$-like receptors in the nucleus accumbens (NAc), reduce PPI such that processing becomes disrupted (Wan and Swerdlow, 1993).

\footnotetext{
*Correspondence: Dr RP Hammer Jr, Department of Psychiatry, Box I007, Tufts-New England Medical Center, 750 Washington St Boston, MA 02 I I I, USA, E-mail: Ron.Hammer@tufts.edu

Received 23 January 2004; revised 9 April 2004; accepted 12 April 2004

Online publication: I4 April 2004 at http://www.acnp.org/citations/ Npp04 | 40404030/default.pdf
}

Repeated treatment with indirect dopamine agonists, such as cocaine or amphetamine, attenuates PPI disruption (Byrnes and Hammer, 2000; Feifel et al, 2002). Furthermore, PPI disruption induced by acute treatment with the $\mathrm{D}_{2}$-like receptor agonist, quinpirole, is completely reversed by longterm treatment (Culm and Hammer, 2004), but the putative substrates underlying such PPI tolerance are poorly understood. The lack of effect of repeated quinpirole treatment on extracellular dopamine release in the NAc, however, suggests that postsynaptic neuroadaptation may occur (Koeltzow et al, 2003).

Acute $\mathrm{D}_{2}$-like receptor stimulation reduces cAMP signaling by decreasing adenylate cyclase activity via $G_{i} / G_{o}$ coupling (Gilman, 1987; Olianas and Onali, 1987). Prolonged activation of such $\mathrm{G}_{\mathrm{i}} / \mathrm{G}_{\mathrm{o}}$-coupled receptors produces heterologous sensitization of cAMP signaling, as occurs in cultured neurons upon stimulation of opiate, $\alpha_{2}$-adrenergic, muscarinic, or adenosine receptors (reviewed by Thomas and Hoffman, 1987), as well as following extended quinpirole exposure (Watts and Neve, 1996). In contrast, $\mathrm{D}_{2}$-like receptor antagonist-induced Fos expression in striatopallidal neurons is dependent on phosphorylation 
of cAMP response element-binding protein (CREB; Konradi and Heckers, 1995; Robertson and Jian, 1995). However, the selective effects of repeated $\mathrm{D}_{2}$-like agonist treatment have not been examined. Modulation of intracellular adenylate cyclase and cAMP-dependent protein kinase (PKA) influence a range of neuronal processes, including protein phosphorylation, regulation of ion channel conductance, and gene expression (for a review see Nestler, 2001). Thus, alteration of cAMP signaling after repeated $\mathrm{D}_{2}$-like agonist treatment might be associated with the elimination of sensorimotor gating deficits. In the present study, our goal was to assess molecular adaptations of cAMP signaling in the NAc induced by long-term treatment with quinpirole, a selective dopamine $\mathrm{D}_{2}$-like receptor agonist, in a paradigm that reverses sensorimotor gating deficits.

\section{MATERIALS AND METHODS}

\section{Animals and Drug Treatment}

In all of the following experiments, rats were provided with food and water ad libitum while housed in a climatecontrolled facility with a $12 \mathrm{~h}$ reverse light/dark cycle (lights off at 0900). Animals were allowed to acclimate to the laboratory for 7 days prior to handling. All experiments were approved by the Tufts-New England Medical Center Animal Care and Use Committee and conducted in accordance with the National Institutes of Health Guide for the Care and Use of Laboratory Animals.

Male Sprague-Dawley rats (Charles River Laboratories, Kingston, RI) weighing $250-300 \mathrm{~g}$ were habituated to handling and subcutaneous (s.c.) saline injection, and placed into a Startle Monitor Behavioral Testing chamber (Hamilton Kinder; Poway, CA) with $70 \mathrm{~dB}$ ambient noise for 5 min daily on each of 2 days prior to baseline PPI testing. Starting 2-3 days later, animals were treated once daily for 28 consecutive days with quinpirole $(0.1 \mathrm{mg} / \mathrm{kg}$, s.c.; RBISigma, Natick, MA) or saline vehicle $(1.0 \mathrm{ml} / \mathrm{kg})$.

\section{Prepulse Inhibition Testing}

Startle amplitude was determined using the Startle Monitor Behavioral Testing System (Hamilton Kinder; Poway, CA) at baseline and after quinpirole administration on treatment days 1 and 28. Each animal was exposed to $70 \mathrm{~dB}$ ambient noise for $5 \mathrm{~min}$ followed by a test session consisting of the randomized presentation of 24 pulse trials $(120 \mathrm{~dB}, 40 \mathrm{~ms}$ pulse), 30 prepulse trials (10 each 73,76 , and $82 \mathrm{~dB}, 20 \mathrm{~ms}$ prepulse given $100 \mathrm{~ms}$ prior to a $120 \mathrm{~dB}, 40 \mathrm{~ms}$ pulse) and 10 trials without pulse or prepulse presentation. The average intertrial interval was $15 \mathrm{~s}$. The acoustic startle response to pulse trials during baseline testing was used to normalize animals into treatment groups such that each group yielded the same mean response to pulse trials. A piezoelectric accelerometer was used to measure response within the chamber. The first drug challenge test session began $10 \mathrm{~min}$ after quinpirole treatment. The percent PPI was calculated using the following equation: $100-(($ mean prepulse trial response/mean pulse trial response) $\times 100)$. The percent prepulse inhibition at each prepulse level and mean pulse trial response data were analyzed using Wilcoxon's signed- rank tests and the Wilcoxon's rank-sum tests with Bonferroni correction for multiple comparisons.

\section{Sample Preparation: Adenylate Cyclase and PKA Assays}

After 28 days of daily saline or quinpirole treatment, PPI was assessed as described above. Rats were challenged the following day with quinpirole, and were anesthetized with sodium pentobarbital $(100 \mathrm{mg} / \mathrm{kg}$, i.p.) and decapitated 25 min later. Brains were removed, frozen at $-30^{\circ} \mathrm{C}$ in 2 methylbutane and stored at $-80^{\circ} \mathrm{C}$ until the day of the assay. Adenylate cyclase and PKA assays were conducted as accomplished previously ( $\mathrm{Lu}$ et al, 2003), as modified from Terwilliger et al (1991). Briefly, brains were sectioned using a $-20^{\circ} \mathrm{C}$ cryostat to a level corresponding to $1.7 \mathrm{~mm}$ anterior to bregma (Paxinos and Watson, 1997). Bilateral $2 \mathrm{~mm}$ wide micropunches containing the entire NAc were obtained from $1 \mathrm{~mm}$ thick tissue slabs, and were sonicated in ice-cold sonication buffer consisting of $20 \mathrm{mM}$ Tris ( $\mathrm{pH}$ 7.4), $1 \mathrm{mM}$ EDTA, $1 \mu \mathrm{M}$ microcystin and protease inhibitors $(1 / 2$ tablet of Complete Mini peptidase inhibitors per $50 \mathrm{ml}$ buffer; Roche Applied Science, Indianapolis, IN). The sample was centrifuged at $20000 \mathrm{~g}$ for $20 \mathrm{~min}$ at $4^{\circ} \mathrm{C}$. The supernatant was transferred into a fresh tube and stored at $-35^{\circ} \mathrm{C}$ for PKA assays. The resulting pellet was resuspended in $150 \mu \mathrm{l}$ of $A C$ buffer containing $20 \mathrm{mM}$ Tris $\mathrm{HCl}(\mathrm{pH} \mathrm{7.4)}$ and $1 \mathrm{mM}$ EDTA for use in adenylate cyclase assays. Protein content in resuspended pellet fractions was calculated using a protein assay kit (BioRad, Hercules, CA).

\section{Adenylate Cyclase Assays}

Resuspended pellet samples were diluted to $0.02 \mu \mathrm{g} / \mu \mathrm{l}$ protein in AC buffer to determine forskolin-stimulated adenylate cyclase activity or diluted to $0.2 \mu \mathrm{g} / \mu \mathrm{l}$ to determine basal and SKF-82958-stimulated adenylate cyclase activity, and DTT was added to a final concentration of $1 \mathrm{mM}$. In a total volume of $100 \mu \mathrm{l}, 25 \mu \mathrm{l}$ of sample protein was mixed with (final concentrations) $50 \mathrm{mM}$ triethanolamine $\mathrm{HCl}$ (pH 7.4), $0.1 \mathrm{mM}$ EGTA, $2 \mathrm{mM} \mathrm{MgCl}_{2}, 1 \mathrm{mM}$ DTT, $1 \mathrm{mM}$ isobutyl-methylxanthine, $0.2 \%$ bovine serum albumin (BSA), $50 \mu \mathrm{M}$ GTP, and $5 \mu \mathrm{M}$ forskolin (in $0.05 \%$ ethanol vehicle) or $10 \mu \mathrm{M}$ SKF 82958. The assay tubes were incubated for $10 \mathrm{~min}$ at $30^{\circ} \mathrm{C}$ before adding $5 \mu \mathrm{l}$ of $1 \mathrm{mM}$ ATP to start the reaction. The assays were terminated $5 \mathrm{~min}$ later by the addition of $0.4 \mathrm{ml}$ of $0.125 \mathrm{M} \mathrm{HCl}$ and frozen at $-35^{\circ} \mathrm{C}$. The next day, the amount of cAMP product in each assay tube was determined using the cAMP ELISA kit (DE0355; R\&D Systems; Minneapolis, MN) according to the instructions for assaying nonacetylated cAMP. A standard curve was utilized to express data in pmol of cAMP per mg of protein per min, and the data were compared using unpaired Student's $t$-tests.

\section{PKA Activity Assays}

Supernatants from the samples were diluted to $0.6 \mu \mathrm{g} / \mu \mathrm{l}$ protein in sonication buffer, and DTT was added to a final concentration of $1 \mathrm{mM}$. In a total volume of $55 \mu \mathrm{l}, 3 \mu \mathrm{g}$ of sample protein was mixed with (final concentrations) $50 \mathrm{mM}$ Tris- $\mathrm{HCl}$ ( $\mathrm{pH}$ 7.4), $1 \mathrm{mM}$ EDTA, $1 \mathrm{mM}$ EGTA, $10 \mathrm{mM} \mathrm{MgCl}_{2}, 0.05 \% \mathrm{NP}-40$ (Sigma-Aldrich, St Louis, 
MO), $10 \mathrm{mM}$ DTT, $15 \mu \mathrm{g}$ histone f2b (Sigma-Aldrich, St Louis, MO), $50 \mu \mathrm{M}^{32} \mathrm{P}$-labeled ATP $(50 \mu \mathrm{Ci} / \mathrm{ml} ; 1 \mu \mathrm{Ci} / \mathrm{nmol})$, and either $1 \mathrm{mM}$ of the PKA activator, 8-bromo-cAMP or $0.1 \mathrm{mg} / \mathrm{ml}$ of the PKA inhibitor (PKI; Sigma-Aldrich, St Louis, MO). The addition of PKI to the assay completely blocks 8-Br-cAMP-induced PKA activity. All samples were run in duplicate. Reactions started with the addition of $1.0 \mu \mathrm{Ci} /$ assay of $\left[\gamma_{-}{ }^{32} \mathrm{P}\right] \mathrm{ATP}$ and were carried out at room temperature for $3 \mathrm{~min}$. Aliquots $(25 \mu \mathrm{l})$ were spotted onto Whatman P81 filter paper $\left(2 \times 2 \mathrm{~cm}^{2}\right)$, which was subsequently washed in distilled water and air-dried. The amount of $\left[\gamma_{-}^{32} \mathrm{P}\right]$ was quantified by liquid scintillation spectrometry. Total PKA activity was determined in the presence of 8-Br-cAMP $(5 \mu \mathrm{M}$, PKA activator; Sigma-Aldrich, St Louis, $\mathrm{MO}$ ), while nonspecific kinase activity was determined in the presence of PKI $(0.1 \mathrm{mg} / \mathrm{ml}$, PKA inhibitor; SigmaAldrich, St Louis, MO). PKA activity was calculated by subtracting nonspecific kinase activity from total kinase activity. Data were expressed as pmol of ATP transferred per mg of sample protein per min and compared using an unpaired Student's $t$-test.

\section{Immunohistochemistry}

Immunohistochemistry was performed on tissues isolated from additional rats treated once daily for 28 days with quinpirole $(0.1 \mathrm{mg} / \mathrm{kg}$, s.c.) or saline vehicle. On the 29 th day, those treated repeatedly with saline were challenged with either quinpirole $(0.1 \mathrm{mg} / \mathrm{kg}$, s.c.) or saline vehicle, while those treated repeatedly with quinpirole were challenged with quinpirole $(0.1 \mathrm{mg} / \mathrm{kg}$, s.c.). At $25 \mathrm{~min}$ after the final saline or quinpirole challenge on the 29th day, sodium pentobarbital ( $100 \mathrm{mg} / \mathrm{kg}$, i.p.) was administered and rats were transcardially perfused with ice-cold $4 \%$ paraformaldehyde, brains were removed and transferred onto graded sucrose supplemented with $50 \mathrm{mM} \mathrm{NaF}$, then stored at $4^{\circ} \mathrm{C}$ for less than 1 week prior to sectioning. Using a sliding microtome, $20 \mu \mathrm{m}$ sections starting at $1.7 \mathrm{~mm}$ anterior to Bregma were collected in $50 \mathrm{mM}$ Tris $\mathrm{HCl}(\mathrm{pH}$ 7.4) containing $50 \mathrm{mM} \mathrm{NaF}$. Sections were mounted onto Fisher SuperFrost Plus microscope slides, air-dried for $30 \mathrm{~min}$ and stored at $-35^{\circ} \mathrm{C}$ prior to immunohistochemical processing.

Phospho-CREB was detected using a polyclonal antibody specific for CREB only when phosphorylated at serine 133 . Total CREB labeling was detected using a polyclonal antibody specific for CREB independent of phosphorylation state. Tissue sections were incubated for $1 \mathrm{~h}$ at $23^{\circ} \mathrm{C}$ in $3 \%$ BSA and $0.4 \%$ Triton $\mathrm{X}$ in $0.1 \mathrm{M}$ potassium phosphatebuffered saline followed by either a $16 \mathrm{~h}$ incubation with phospho-CREB antisera (1:500; Cell Signaling Technology, Beverly, MA) or a $48 \mathrm{~h}$ incubation with CREB antisera (1:1250; Cell Signaling Technology, Beverly, MA) at $4^{\circ} \mathrm{C}$. Sections were incubated in goat anti-rabbit secondary antiserum for $1 \mathrm{~h}$ followed by avidin-biotin-peroxidase reagents (Elite Vectastain Kit; Vector Laboratories, Burlingame, CA) for $45 \mathrm{~min}$ at $23^{\circ} \mathrm{C}$, and chromagen development in $0.33 \% \mathrm{NiCl}_{2} / 0.05 \% \mathrm{DAB} / 0.03 \% \mathrm{H}_{2} \mathrm{O}_{2}$ in $100 \mathrm{mM}$ Tris $\mathrm{HCl}$ for $5 \mathrm{~min}$. Some tissue sections were incubated in the same antisera preadsorbed with phospho-CREB blocking peptide (1:10; Cell Signaling Technology, Beverly, MA).
The number of immunostained profiles within the NAc core located adjacent and dorsomedial to the anterior commissure, the central portion of the NAc shell, as well as medial and lateral regions of the caudatoputamen in sections located approximately $1.6 \mathrm{~mm}$ anterior to Bregma was determined using Image Pro Plus analysis software (v. 4.1.0.0, Media Cybernetics; Carlsbad, CA). Sample areas $\left(49000 \mu \mathrm{m}^{2}\right.$ in size) were digitized from three to five sections per brain using a Cool Snap Pro video camera on an Olympus BH-2 microscope. In order to reduce background staining in the analysis, the mean intensity in cellfree regions was measured across all experimental tissues, and this background level was subtracted to eliminate nonspecific labeling in each section. A density threshold was applied across all experimental tissues and the number of immunoreactive nuclear profiles above this threshold was determined by the software. In order to exclude partial profiles, only those larger than 500 square pixels but smaller than 1500 square pixels were included. Data from each brain region were analyzed using a one-way analysis of variance followed by Student-Newman-Keuls post hoc test to determine the locus of main effects.

\section{Infusion of PKA Activator}

An additional series of rats received bilateral guide cannulas directed at the NAc (AP: $+0.17 \mathrm{~mm}$ anterior to bregma; ML: $\pm 0.30 \mathrm{~mm}$; and DV: $-5.3 \mathrm{~mm}$ from dura mater; Paxinos and Watson, 1997). Dummy cannulas were inserted to maintain patency. Baseline PPI was determined as described above both prior to stereotaxic surgery and after 1 week recovery to normalize groups and ensure that PPI level was unaffected by surgery. Starting 1 week later, injection cannulas extending $1 \mathrm{~mm}$ beyond the guide cannula were inserted into the NAc. The PKA activator, 8-bromo-adenosine $3^{\prime}, 5^{\prime}$-cyclic monophosphorothiote (Sp-cAMPS, $80 \mathrm{nmol}$ in $1 \mu \mathrm{l}$ per side; Calbiochem, San Diego, CA), or saline vehicle was infused over a $5 \mathrm{~min}$ period utilizing a motorized syringe pump. After $30 \mathrm{~min}$, at a time when Sp-cAMPS infusion into the NAc is maximally effective (Self et al, 1998), animals received quinpirole $(0.1 \mathrm{mg} / \mathrm{kg}$, s.c. $)$ or saline vehicle, followed $10 \mathrm{~min}$ later by PPI testing as described above. On four separate occasions 3-4 days apart, each rat received either intracranial SpcAMPS or vehicle with acute challenge of quinpirole, or intracranial Sp-cAMPS or vehicle with acute challenge of saline; the order of trials was counterbalanced to eliminate possible pretreatment effects. Data were analyzed using a Kruskal-Wallis analysis of variance with repeated measures followed by Bonferroni post hoc comparison. Following these experiments, brains were removed and the location of the injection cannula tip was determined.

\section{RESULTS}

\section{PPI Recovery after Repeated Quinpirole Administration}

Acute treatment with quinpirole significantly reduced PPI following 73,76 , or $82 \mathrm{~dB}$ prepulses by 16,18 , and $14 \%$, respectively compared to vehicle treatment (Figure 1). After 28 days of repeated quinpirole administration, PPI significantly increased compared to day 1 treatment levels, 


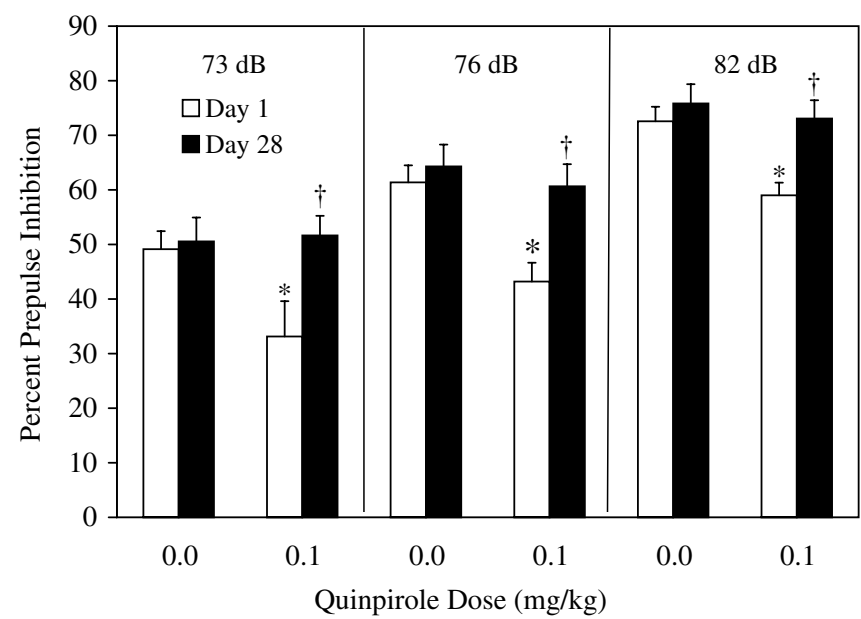

Figure I Complete recovery of PPI occurs after 28 days repeated quinpirole treatment. Quinpirole was administered once daily and the effect of drug treatment on PPI was assessed on days I and 28. The percent PPI (mean \pm SEM) was calculated from data obtained using prepulses 3,6 , or $12 \mathrm{~dB}$ above ambient noise level $(70 \mathrm{~dB})$. Each treatment group contained 18 animals. *Significant $(p<0.05)$ difference compared to same day PPI in vehicle group. 'Significant $(p<0.05)$ difference compared to day I PPI after quinpirole treatment.

Table I Effect of Acute and 28-Day Treatment on Mean Acoustic Startle Response

Quinpirole dose (mg/kg)

\begin{tabular}{lcc}
\cline { 2 - 3 } & $\mathbf{0}$ & $\mathbf{0 . 1}$ \\
\hline Day I & $0.39 \pm 0.05$ & $0.35 \pm 0.05$ \\
Day 28 & $0.46 \pm 0.08$ & $0.31 \pm 0.04$ \\
\hline
\end{tabular}

Data are expressed as mean \pm SEM startle response in Newtons. Treatment groups contain 18 animals.

indicating that a complete recovery of PPI occurred with repeated $\mathrm{D}_{2}$-like receptor agonist treatment. Neither mean acoustic startle response to pulse trials (Table 1) nor responses in the presence of ambient noise only (data not shown) were altered by acute or repeated quinpirole treatment.

\section{Adaptations in cAMP Signaling after Repeated Quinpirole Treatment}

Quinpirole challenge after repeated quinpirole treatment had no effect on basal adenylate cyclase activity compared to quinpirole challenge after saline treatment (acute: $86.8 \pm 6.0 \mathrm{pmol} / \mathrm{mg} / \mathrm{min}$; repeated: $90.8 \pm 6.8 \mathrm{pmol} / \mathrm{mg} / \mathrm{min}$; Figure 2). Adenylate cyclase activity measured using forskolin $(5 \mu \mathrm{M})$ was also unaffected by quinpirole treatment (acute: $530.4 \pm 70.4 \mathrm{pmol} / \mathrm{mg} / \mathrm{min}$; repeated: $498 \pm 75.2 \mathrm{pmol} / \mathrm{mg} / \mathrm{min})$. Furthermore, when dopamine $\mathrm{D}_{1}$-like receptors were stimulated with SKF $82958(10 \mu \mathrm{M})$, no difference in cAMP accumulation was observed between treatment groups (acute: $172.3 \pm 12.5 \mathrm{pmol} / \mathrm{mg} / \mathrm{min}$; repeated: $185.9 \pm 8.8 \mathrm{pmol} / \mathrm{mg} / \mathrm{min})$.

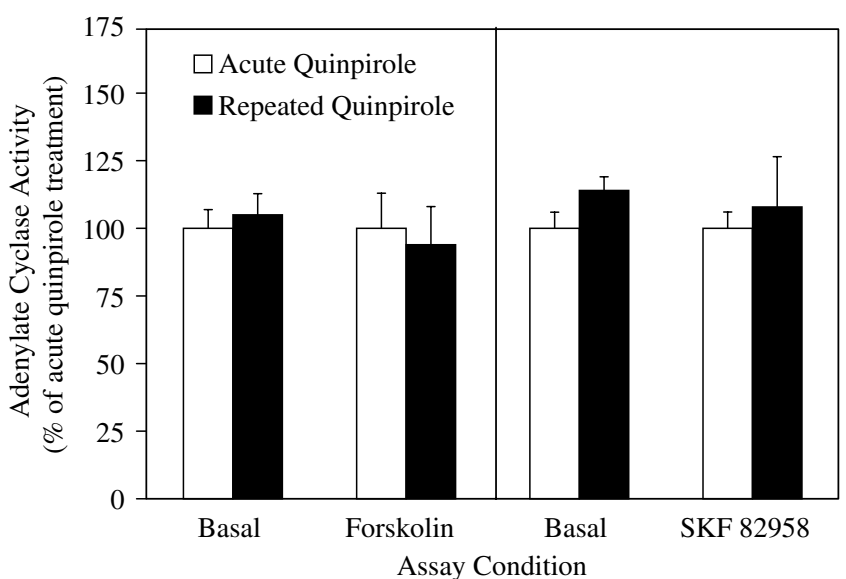

Figure 2 Repeated quinpirole treatment does not alter NAc adenylate cyclase activity. Adenylate cyclase activity was determined by measuring cAMP accumulation following forskolin $(5 \mu \mathrm{M}$, using $0.5 \mu \mathrm{g}$ protein in the assay; $n=9$ per group) or SKF 82958 ( $10 \mu \mathrm{M}$, using $5.0 \mu \mathrm{g}$ protein in the assay; $n=7$ per group) stimulation. Data (mean \pm SEM) are expressed as the percent of acute treatment. Open bars: repeated saline followed by quinpirole challenge; solid bars: repeated quinpirole followed by quinpirole challenge.

The effect of long-term quinpirole treatment on signaling was further characterized by assessing PKA activity. In cytosolic NAc fractions, PKA activity increased significantly by $66 \%$ upon quinpirole challenge after repeated quinpirole (repeated; $n=5$ ) treatment compared to quinpirole challenge following repeated saline (acute; $n=6$ ) treatment (acute: $1299.0 \pm 254.3 \mathrm{pmol} / \mathrm{mg} / \mathrm{min}$; repeated: $2156.7 \pm 170.5 \mathrm{pmol} / \mathrm{mg} / \mathrm{min} ; p \leqslant 0.05)$.

Immunohistochemical data revealed that the phosphorylation state of CREB was altered by repeated quinpirole treatment in the NAc, but not in the caudatoputamen. Phospho-CREB labeling was quite low in the NAc upon acute quinpirole challenge (Figure 3a), exhibiting slightly lower levels in the NAc core and shell compared to vehicle treatment (Figure 4). In contrast, the number of phospho-CREB-like immunoreactive profiles in both regions of the NAc increased significantly upon quinpirole challenge after repeated quinpirole treatment compared to repeated saline treatment with or without acute quinpirole challenge (Figures $3 \mathrm{~b}$ and 4). For example, repeated quinpirole treatment increased phospho-CREB labeling in the NAc core 2.5 -fold compared to repeated saline treatment and nearly 3.5 -fold compared to acute quinpirole treatment. However, repeated quinpirole treatment had no significant effect on the number of phospho-CREB-like immunoreactive profiles in either medial or lateral caudatoputamen (Figures $3 c, d$ and 4). In fact, no phospho-CREB labeling above threshold density was present in the caudatoputamen $f$ ollowing repeated quinpirole treatment (Figure 4). Selectivity of labeling for phospho-CREB was confirmed by complete elimination of labeling after preadsorption (data not shown). Finally, the total number of NAc neurons expressing CREB protein compared to vehicle treatment was unchanged after repeated quinpirole treatment (Table 2). 

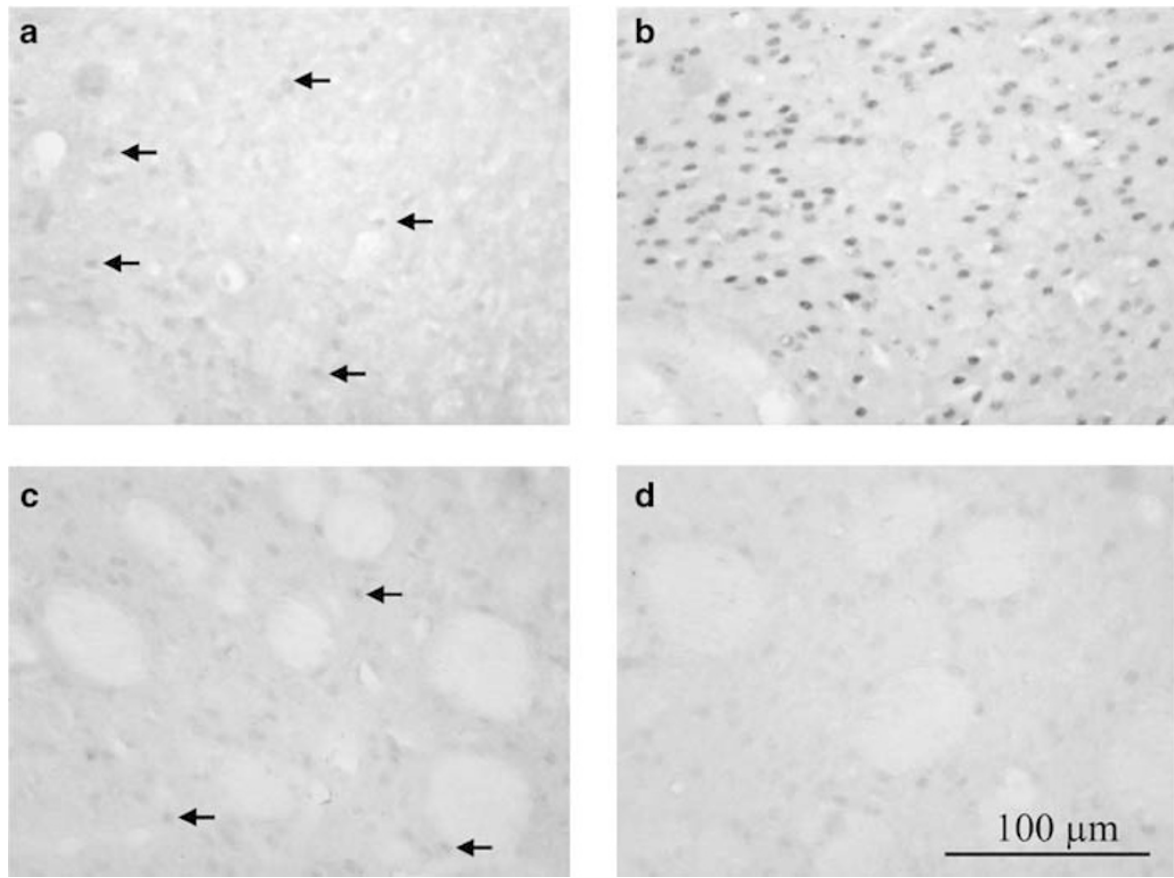

Figure 3 Effect of acute and repeated quinpirole treatment on phospho-CREB induction in the NAc and caudatoputamen. Rats were treated with quinpirole or saline vehicle for 28 days. The following day, both rats received quinpirole challenge, and brain sections were processed for phospho-CREB immunohistochemistry. Few lightly stained nuclei (arrows) are visible following acute quinpirole in the NAc core (a) and lateral caudatoputamen (c), while abundant, intense nuclear labeling is present after repeated treatment in the NAc core (b), but not in the lateral caudatoputamen (d). The anterior commissure is shown at the lower left in (a) and (b) adjacent to the NAc core. All illustrations were photographed at $\times 200$ (original magnification); a calibration bar is shown at the lower right in (d).

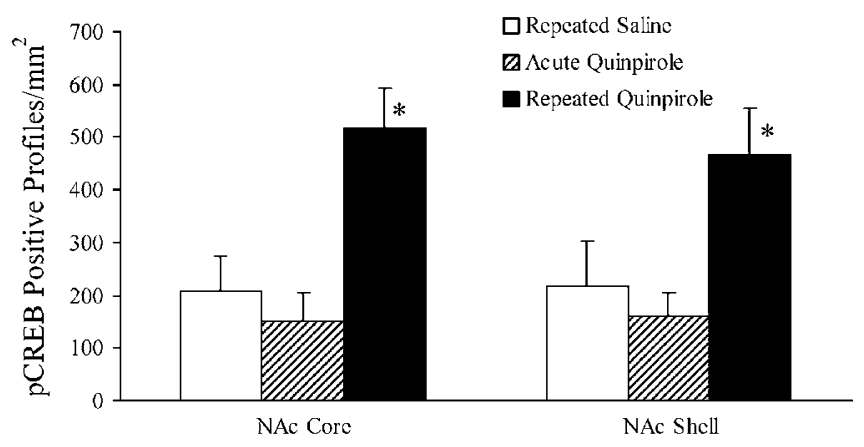

Figure 4 Repeated quinpirole treatment induces phospho-CREB in the NAc core and shell, but not in the caudatoputamen. Rats were treated with quinpirole or saline vehicle for 28 days. The following day, saline-treated rats received quinpirole (acute quinpirole) or saline (repeated saline) challenge, while quinpirole-treated rats received quinpirole (repeated quinpirole) challenge prior to processing for phospho-CREB immunohistochemistry. Data are expressed as the number of nuclear profiles (mean \pm SEM) per $\mathrm{mm}^{2}$ with greater than a fixed threshold density value. Treatment groups contain seven to eight animals. *Significant $(p<0.05)$ difference compared to vehicle and acute treatment; $N A c=$ nucleus accumbens; $\mathrm{CP}=$ caudatoputamen; $\mathrm{PCREB}=$ phospho- $\mathrm{CREB}$.

\section{PKA Activation and Quinpirole-Induced PPI Disruption}

Histological examination confirmed that all injection cannulas targeted the central NAc, midway between the NAc core and shell. Infusions therefore affected both NAc core and shell. Systemic quinpirole treatment significantly
Table 2 Effect of 28-Day Treatment on CREB Expression in the $\mathrm{NAc}$

\begin{tabular}{lcc}
\hline & \multicolumn{2}{c}{ Quinpirole dose $\mathbf{( m g / k g )}$} \\
\cline { 2 - 3 } & $\mathbf{0}$ & $\mathbf{0 . 1}$ \\
\hline NAc core & $717.9 \pm 89.8$ & $681.2 \pm 49.8$ \\
NAc shell & $558.6 \pm 99.3$ & $602.2 \pm 63.0$
\end{tabular}

Data are expressed as the number of CREB-positive nuclear profiles (mean \pm SEM) per $\mathrm{mm}^{2}$. Treatment groups contain seven to eight animals.

reduced PPI following 73, 76, and $82 \mathrm{~dB}$ prepulses (Figure 5). Infusion of Sp-cAMPS alone into the NAc produced a slight reduction of PPI, which was significant only after $76 \mathrm{~dB}$ prepulses. Nevertheless, infusion of Sp-cAMPS into the NAc prevented quinpirole-induced PPI disruption at all prepulse levels.

\section{DISCUSSION}

Repeated treatment with the selective $\mathrm{D}_{2}$-like receptor agonist, quinpirole, reversed the PPI deficit induced by acute quinpirole. Stimulation of $\mathrm{D}_{2}$-like receptors disrupts PPI via coupling to $\mathrm{G}_{\alpha \mathrm{i}} / \mathrm{G}_{\alpha \mathrm{o}}$ proteins in the NAc (Culm et al, 2003), implicating the involvement of adenylate cyclase and PKA in this brain region. However, repeated quinpirole 


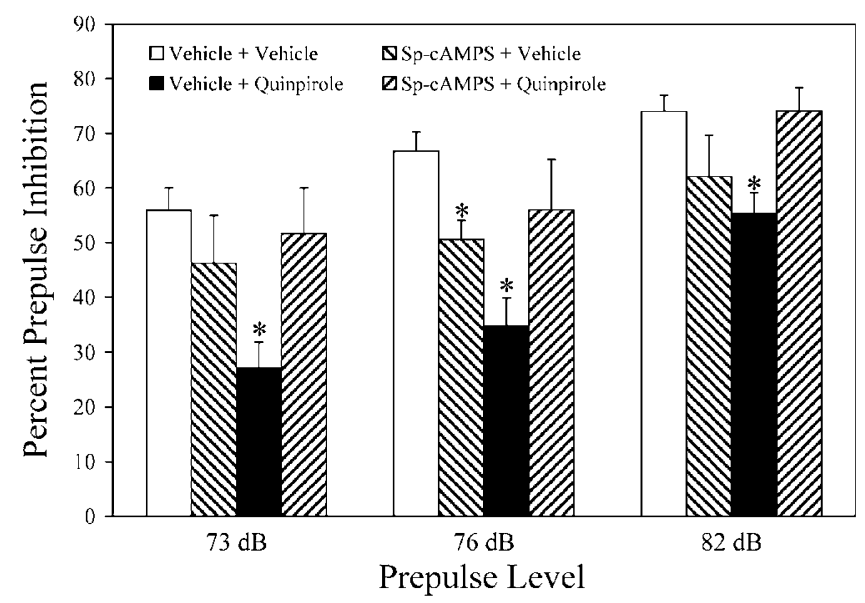

Figure 5 PKA activation in the NAc prevents acute quinpirole-induced PPI disruption. Intracranial Sp-cAMPS or vehicle administration occurred 30 min prior to systemic quinpirole or vehicle treatment. PPI testing was initiated $10 \mathrm{~min}$ after systemic challenge. The percent PPI (mean \pm SEM) was calculated from data obtained using prepulse levels 3 , 6, or $12 \mathrm{~dB}$ above ambient noise level $(70 \mathrm{~dB})$. Treatment groups contain four to 16 animals. *Significant $(p<0.05)$ difference compared to intracranial and systemic vehicle treatment.

treatment at the dose used herein does not alter $\mathrm{G}$ protein level or function in the NAc, despite complete reversal of the PPI deficit induced by acute quinpirole (Culm and Hammer, 2004). The data reveal that repeated quinpirole treatment did not alter adenylate cyclase activity, having no effect on basal, forskolin-stimulated or $\mathrm{D}_{1}$-like agoniststimulated cAMP accumulation (Figure 2), although only single concentrations of forskolin and SKF 82958 were utilized. Our results in the intact brain, however, differ from the results of an in vitro study where prolonged (ie $2 \mathrm{~h}$ ) stimulation of $\mathrm{D}_{2}$-like receptors by quinpirole increased adenylate cyclase activity (Watts and Neve, 1996).

Adenylate cyclase activity was unaffected by repeated quinpirole administration despite a significant increase in PKA activity. This suggests that the same level of cAMP might differentially affect PKA due to enhanced activity or amount of the latter enzyme in the NAc. Such enhanced PKA activity following repeated quinpirole treatment could underlie increased phospho-CREB expression in the NAc (Figures 3 and 4). However, PKA is only one of several kinases known to phosphorylate CREB. For example, protein kinase B/Akt, protein kinase $\mathrm{C}$, and $\mathrm{Ca}^{2+} /$ calmodulin-dependent protein kinase all are implicated in quinpirole-mediated phosphorylation of CREB (BramiCherrier et al, 2002; Yan et al, 1999). Thus, repeated quinpirole treatment can lead to phosphorylation of CREB in various ways, which might explain why phosphoCREB labeling in the NAc increased more than twice as much as NAc PKA activity after repeated quinpirole treatment.

\section{Increased PKA Activity in the NAC Attenuates PPI Disruption}

PKA activation produced by infusion of Sp-cAMPS into the NAc prevents quinpirole-induced PPI disruption, although
PPI returns to the level observed after vehicle treatment only after $82 \mathrm{~dB}$ prepulses (Figure 5). Such local PKA activation affects all NAc core and shell efferent neurons, including both those that express predominantly $\mathrm{D}_{1}$-like receptors and those that express $\mathrm{D}_{2}$-like receptors (Robertson and Jian, 1995). $D_{1}$-like receptor stimulation is necessary but not sufficient to produce PPI disruption, except at the highest doses of agonist (Swerdlow et al, 2000), although it can enhance disruptive effects of $\mathrm{D}_{2}$-like receptor stimulation (Wan et al, 1996). Thus, activation of PKA in NAc neurons that express predominantly $D_{1}$-like receptors might potentiate disruption, thereby limiting the action of $\mathrm{Sp}$-cAMPS on $\mathrm{D}_{2}$-like receptor-expressing neurons to reverse quinpirole-induced PPI disruption. Nevertheless, the attenuation of PPI disruption produced by PKA activation in the NAc suggests that enhanced NAc PKA signaling underlies the reversal of sensorimotor gating deficits following repeated quinpirole treatment.

We observed that repeated quinpirole treatment induced phospho-CREB labeling in both NAc core and shell neurons, with slightly more induction present in the NAc core (Figure 4). The NAc core is somewhat more sensitive to acute quinpirole-induced PPI disruption (Wan et al, 1994), perhaps because $D_{2}$-like receptor density is greater in the NAc core than the shell (Bardo and Hammer, 1991). The concurrence of PPI tolerance with phospho-CREB induction selectively in the NAc implicates CREB in the regulation of sensorimotor gating. CREB is a major transcription factor associated with memory and learning as well as with molecular and behavioral adaptations after long-term drug administration (Duman, 2002). Long-term experimental alteration of CREB function in the NAc has been shown to alter behavior. For example, overexpression of dominantnegative mutant CREB, in which a substitution of serine 133 by alanine prevents CREB phosphorylation and inhibits endogenous CREB function, augments responses to anxiogenic or nociceptive stimuli (Barrot et al, 2002), elicits an antidepressant response (Newton et al, 2002), and increases the rewarding effect of cocaine (Carlezon et al, 1998). In contrast, overexpression of CREB in the NAc diminishes an animal's response to anxiogenic or nociceptive stimuli (Barrot et al, 2002) and reduces the rewarding effect of cocaine (Carlezon et al, 1998). Thus, CREB activation in the NAc following repeated quinpirole treatment might affect gene expression to promote PPI recovery.

Several nucleotide sequence variants have been identified in the promoter region of the CREB gene that might contribute to susceptibility to schizophrenia, especially involving cognitive symptoms (Kawanishi et al, 1999). Furthermore, haloperidol or eticlopride treatment induce CREB phosphorylation (Pozzi et al, 2003) and increase PKA activity (Dwivedi et $a l, 2002$ ) in striatum. Thus, neuroadaptation in response to repeated quinpirole treatment may produce antipsychotic-like effects on PKA and CREB in NAc efferent neurons. The regional selectivity of repeated quinpirole effects in the ventral striatum, then, might obviate the development of extrapyramidal side effects mediated by the dorsal striatum. Activated CREB stimulates transcription of various genes containing a cAMP response element in their promoter region, including serotonin $2 \mathrm{~A}$ receptors, tyrosine hydroxylase, and others implicated in schizophrenia. Long-term $\mathrm{D}_{2}$-like receptor agonist therapy 
might thereby alter endogenous mechanisms mediating PPI disruption to facilitate recovery of sensorimotor gating in schizophrenia and in other neuropsychiatric disorders manifesting altered PPI. In fact, clinical research studies utilizing $\mathrm{D}_{2}$-like receptor agonists such as talipexole, roxindole, and pramipexole have demonstrated mild improvement, particularly in negative symptoms of schizophrenia (Benkert et al, 1995; Kasper et al, 1992; Ohmori et al, 1993), while aripiprazole, a $\mathrm{D}_{2}$-like receptor partial agonist and serotonin ${ }_{2 \mathrm{~A}}$ receptor antagonist, is effective for both positive and negative symptoms (Potkin et al, 2003). The compensatory mechanisms described herein might underlie, in part, the clinical efficacy of $\mathrm{D}_{2}$-like receptor agonist therapy for schizophrenia.

\section{ACKNOWLEDGEMENTS}

This work was supported by USPHS award R01 MH60251 and MH66954 to RPH. NL-E was supported by T35 HL007785 to Tufts University. We thank Drs Christine Konradi for generous advice on phospho-CREB immunohistochemistry and Antonio Lim for assistance with studies using Sp-cAMPS.

\section{REFERENCES}

Bardo MT, Hammer RP (1991). Autoradiographic localization of $\mathrm{D}_{1}$ and $\mathrm{D}_{2}$ receptors in rat nucleus accumbens: resistance to differential rearing conditions. Neuroscience 45: 281-290.

Barrot M, Olivier JD, Perrotti LI, DiLeone RJ, Berton O, Eisch AJ et al (2002). CREB activity in the nucleus accumbens shell controls gating of behavioral responses to emotional stimuli. Proc Natl Acad Sci (USA) 99: 11435-11440.

Benkert O, Muller-Siecheneder F, Wetzel H (1995). Dopamine agonists in schizophrenia: a review. Eur Neuropsychopharmacol 5: 43-53.

Brami-Cherrier K, Valjent E, Garcia M, Pages C, Hipskind RA, Caboche J (2002). Dopamine induces a PI3-kinase-independent activation of Akt in striatal neurons: a new route to cAMP response element-binding protein phosphorylation. J Neurosci 22: 8911-8921.

Byrnes JJ, Hammer RP (2000). The disruptive effect of cocaine on prepulse inhibition is prevented by repeated administration in rats. Neuropsychopharmacology 22: 551-554.

Carlezon Jr WA, Thome J, Olson VG, Lane-Ladd SB, Brodkin ES, Hiroi $\mathrm{N}$ et al (1998). Regulation of cocaine reward by CREB. Science 282: 2272-2275.

Culm KE, Hammer RP (2004). Recovery of sensorimotor gating deficits without $G$ protein adaptation after repeated $D_{2}$-like dopamine receptor agonist treatment in rats. J Pharmacol Exp Ther 308: 487-494.

Culm KE, Lim AM, Onton JA, Hammer RP (2003). Reduced $G_{i}$ and $G_{o}$ protein function in the rat nucleus accumbens attenuates sensorimotor gating deficits. Brain Res 982: 12-18.

Duman RS (2002). Synaptic plasticity and mood disorders. Mol Psychiatry 7: S29-S34.

Dwivedi Y, Rizavi HS, Pandey GN (2002). Differential effects of haloperidol and clozapine on [3H]cAMP binding, protein kinase A (PKA) activity, and mRNA and protein expression of selective regulatory and catalytic subunit isoforms of PKA in rat brain. J Pharmacol Exp Ther 301: 197-209.

Feifel D, Priebe K, Johnstone-Miller E, Morgan CJ (2002). Sensorimotor gating effects produced by repeated dopamine agonists in a paradigm favoring environmental conditioning. Psychopharmacology (Berl) 162: 138-146.

Gilman AG (1987). G proteins: transducers of receptor-generated signals. Annu Rev Biochem 56: 615-649.

Kawanishi Y, Harada S, Tachikawa H, Okubo T, Shiraishi H (1999). Novel variants in the promoter region of the CREB gene in schizophrenic patients. J Hum Genet 44: 428-430.

Kasper S, Fuger J, Zinner HJ, Bauml J, Moller HJ (1992). Early clinical results with the neuroleptic roxindole (EMD 49,980) in the treatment of schizophrenia-an open study. Eur Neuropsychopharmacol 2: 91-95.

Koeltzow TE, Austin JD, Vezina P (2003). Behavioral sensitization to quinpirole is not associated with increased nucleus accumbens dopamine overflow. Neuropharmacology 44: 102-110.

Konradi C, Heckers S (1995). Haloperidol-induced Fos expression in striatum is dependent upon transcription factor cyclic AMP response element binding protein. Neuroscience 65: 1051-1061.

Lu L, Grimm JW, Shaham Y, Hope BT (2003). Molecular neuroadaptations in the accumbens and ventral tegmental area during the first 90 days of forced abstinence from cocaine selfadministration in rats. $J$ Neurochem 85: 1604-1613.

Nestler EJ (2001). Molecular basis of long-term plasticity underlying addiction. Nat Rev Neurosci 2: 119-128.

Newton SS, Thome J, Wallace TL, Shirayama Y, Schlesinger L, Sakai $\mathrm{N}$ et al (2002). Inhibition of cAMP response elementbinding protein or dynorphin in the nucleus accumbens produces an antidepressant-like effect. J Neurosci 22: 1088310890.

Ohmori T, Koyama T, Inoue T, Matsubara S, Yamashita I (1993). B-HT 920, a dopamine D2 agonist, in the treatment of negative symptoms of chronic schizophrenia. Biol Psychiatry 33: 687-693.

Olianas MC, Onali P (1987). Pertussis toxin attenuates $D_{2}$ inhibition and enhances $D_{1}$ stimulation of adenylate cyclase by dopamine in rat striatum. J Neurochem 48: 1443-1447.

Paxinos G, Watson C (1997). The Rat Brain in Stereotaxic Coordinates. Academic Press: New York.

Potkin SG, Saha AR, Kujawa MJ, Carson WH, Ali M, Stock E et al (2003). Aripiprazole, an antipsychotic with a novel mechanism of action, and risperidone $v s$ placebo in patients with schizophrenia and schizoaffective disorder. Arch Gen Psychiatry 60: 681-690.

Pozzi L, Hakansson K, Usiello A, Borgkvist A, Lindskog M, Greengard $\mathrm{P}$ et al (2003). Opposite regulation by typical and atypical anti-psychotics of ERK1/2, CREB and Elk-1 phosphorylation in mouse dorsal striatum. J Neurochem 86: 451-459.

Robertson GS, Jian $M$ (1995). $D_{1}$ and $D_{2}$ dopamine receptors differentially increase Fos-like immunoreactivity in accumbal projections to the ventral pallidum and midbrain. Neuroscience 64: 1019-1034.

Self DW, Genova LM, Hope BT, Barnhart WJ, Spencer JJ, Nestler EJ (1998). Involvement of cAMP-dependent protein kinase in the nucleus accumbens in cocaine self-administration and relapse of cocaine-seeking behavior. J Neurosci 18: 1848-1859.

Swerdlow NR, Martinez ZA, Hanlon FM, Platten A, Farid M, Auerbach P et al (2000). Toward understanding the biology of a complex phenotype: rat strain and substrain differences in the sensorimotor gating-disruptive effects of dopamine agonists. $J$ Neurosci 20: 4325-4336.

Terwilliger RZ, Beitner-Johnson D, Sevarino KA, Crain SM, Nestler EJ (1991). A general role for adaptations in G-proteins and the cyclic AMP system in mediating the chronic actions of morphine and cocaine on neuronal function. Brain Res 548: $100-110$.

Thomas JM, Hoffman BB (1987). Adenylate cyclase supersensitivity: a general means of cellular adaptation to inhibitory agonists. Trends Pharmacol Sci 8: 308-311. 
Wan FJ, Geyer MA, Swerdlow NR (1994). Accumbens $\mathrm{D}_{2}$ modulation of sensorimotor gating in rats: assessing anatomical localization. Pharmacol Biochem Behav 49: 155-163.

Wan FJ, Swerdlow NR (1993). Intra-accumbens infusion of quinpirole impairs sensorimotor gating of acoustic startle in rats. Psychopharmacology 113: 103-109.

Wan FJ, Taaid N, Swerdlow NR (1996). Do $D_{1} / D_{2}$ interactions regulate prepulse inhibition in rats? Neuropsychopharmacology 14: 265-274.
Watts VJ, Neve KA (1996). Sensitization of endogenous and recombinant adenylate cyclase by activation of $\mathrm{D}_{2}$ dopamine receptors. Mol Pharmacol 50: 966-976.

Yan Z, Feng J, Fienberg AA, Greengard P (1999). $D_{2}$ dopamine receptors induce mitogen-activated protein kinase and cAMP response element-binding protein phosphorylation in neurons. Proc Natl Acad Sci (USA) 96: 1 1607-11612. 